\title{
Subchronic Toxicity of Green Algae (Spyrogyra sp.) Ethanolic Extract on Hematologic Parameters
}

\author{
Nina Salamah, Wahyu Widyaningsih, Hari Susanti, Anggita Devi, Anita Wening Sejati, \\ Zahra Alya Putri \\ Department of Pharmacy, Universitas Ahmad Dahlan, Indonesia
}

\begin{tabular}{|c|c|}
\hline Article Info & ABSTRACT \\
\hline Article history: & \multirow{10}{*}{$\begin{array}{l}\text { Green Algae, an organism with active substance such as phytomelatonin, has } \\
\text { potential to be developed as Indonesian traditional medicine. As the long } \\
\text { term addition of Green Algae ethanol extract (Ekstrak etanol ganggang } \\
\text { hijau, EEGH) influences the hematology system, in this paper, the safety test } \\
\text { was done to ensure the safety of its use through subchronic toxicity test of } \\
\text { EEGH on the hematology parameters of Wistar rats. The test group consisted } \\
\text { of three groups treated with EEGH } 100 \mathrm{mg} / \mathrm{kg}, 200 \mathrm{mg} / \mathrm{kg} \text {, and } 400 \mathrm{mg} / \mathrm{kg} \text {, } \\
\text { while the control group was given by } 0.5 \% \text { CMC-Na, with } 8 \text { rats each } \\
\text { respectively. By using blood samples taken from orbital sinus on the } 29^{\text {th }} \\
\text { day, common hematologic parameters (erythrocytes, leukocytes, and } \\
\text { hemoglobin level), the parameters of hemostasis (platelets, pT, aPTT, BT) } \\
\text { and immune parameters (Differential Leukocytes Counts include neutrophils } \\
\text { segment, lymphocytes, monocytes, and eosinophils) were finally observed } \\
\text { and showed that the } 28 \text { days-addition of EEGH increase the hematological } \\
\text { parameters of Wistar rats. }\end{array}$} \\
\hline Received Jan 6, 2015 & \\
\hline Revised Mar 2, 2016 & \\
\hline Accepted Mar 16, 2016 & \\
\hline Keyword: & \\
\hline Green algae & \\
\hline Hematologic & \\
\hline Homeostasis & \\
\hline Spirogyra sp & \\
\hline Subcronic toxicity & \\
\hline
\end{tabular}

Copyright (c) 2016 Institute of Advanced Engineering and Science. All rights reserved.

Corresponding Author:

Nina Salamah,

Department of Pharmacy,

Universitas Ahmad Dahlan,

J1 Prof Soepomo, Janturan, Yogyakarta-55165, Indonesia.

Email: syifaniputri@yahoo.com

\section{INTRODUCTION}

Green algae (Spirogyra sp.) are a thred like green algae. Its body is made up of cells that form elongated strands as a threadlike. Each of its cells has chloroplasts with a ribbon-shaped; Seeds spiral with a cell nucleus; Proliferation vegetatively through fragmentation and generative proliferation through conjugation. Green algae (Spirogyra sp.) live in sea water, fresh water, and humid place. Green algae could live free but there are also colonized. The algae have chlorophyll and yellow substance (carotene) that appear greenish-yellow. Green algae (Spirogyra sp.) have the active substance in the form of melatonin, which melatonin compounds present in plants is often referred to as phytomelatonin [1].

In a previous study reported that melatonin may help prevent breast cancer and prostate cancer [2]. Another benefit of melatonin is an antioxidant [3], to prevent kidney damage which is caused by smoking [4], to address the myocardial damage due to nicotine [5], preventing cerebral hemorrhage [6], inhibits neurotoxic of arsenic [7], as an anti-mouth cancer [8], and anti-hypertension [9]. Due to the importance of the function phytomelatonin compounds, therefore the study of compounds phytomelatonin needs to be conducted [10].

Based on the description above, researchers conduct research on the effects of long-term treatment (subchronic) ethanol extract of green algae (Spirogyra sp.) on the hematologic picture of Wistar male rats, and to identify the toxic effects after giving ethanol extract of green algae (Spirogyra sp.). 


\section{RESEARCH METHOD}

This study used 32 male rats Wistar -2-3 months old with a weight range of 150-200 grams. The research design was, 32 rats divided into 4 groups and each group comprised 8 tails. Before treatment the rats have adapted for one week, then treated for 28 days with orally injected every day. The treatments of each group were as follows:

Group I : As a control treated with a solution of $\mathrm{Na} 0.5 \% \mathrm{CMC}$ suspension

Group II : Given the suspension of ethanolic extract of green algae orally at a dose of $100 \mathrm{mg} / \mathrm{kg} \mathrm{bw}$ (green algae ethanol extract $100 \mathrm{mg} / \mathrm{kg}$ ).

Group III : Given the suspension of ethanolic extract of green algae orally at a dose of $200 \mathrm{mg} / \mathrm{kg}$ bw (green algae ethanol extract $200 \mathrm{mg} / \mathrm{kg}$ ).

Group IV : Given the suspension of ethanolic extract of green algae orally at a dose of $400 \mathrm{mg} / \mathrm{kg}$ bw (green algae ethanol extract $400 \mathrm{mg} / \mathrm{kg}$ ).

The last day (after 28 days treatment) rat have blood drawn through orbital sinus and analyzed of value of erythrocytes, leukocytes, leukocyte count, count the number of platelets, PT, aPTT, BT and hemoglobin levels. Then the results analyzed statistically and compared with normal hematologic values rat [11].

\section{RESULTS AND ANALYSIS}

Green algae that have been pollinated and macerated with $96 \%$ ethanol produced the extracts viscous solid green characteristic with odor of green algae.

Hematological examination is very important in the diagnosis of a disorder or functional damage to organs or tissues, this is due to hematologic examination may show an overview of the functions of organs and physiological status. Blood samples have taken via the orbital sinus white rat using capillary tube. A clean Ependorf that has been given Ethylene Diamine Tetra Acid (EDTA) has used to accommodate the blood. EDTA used as an anticoagulant. Blood sampling performed in all groups of rat on day 28 [12].

\subsection{General Hematological Parameter}

Test for common hematological parameters conducted to determine how the effect of subchronic EEGH can affect the erythrocytes, leukocytes, and hemoglobin concentration [13]. All results are summarized in Table 1. Values have shown in the reduction or increase in the number and levels that have adjusted to normal levels in the blood of Wistar rats.

Table 1. The Results of Calculation General Hematological Parameters of Rat after Ethanolic Extract of

\begin{tabular}{ccc} 
& Green Algae were given for 28 Days \\
\hline Group & Dosage $(\mathrm{mg} / \mathrm{kg} \mathrm{bw})$ & $\mathrm{X} \pm \mathrm{SD}(\mathrm{g} / \mathrm{dL})$ \\
\hline Erythrocyte & Control & $5.325 \pm 0.54$ \\
& 100 & $7.562 \pm 0.25^{*}$ \\
& 200 & $6.466 \pm 0.43^{*}$ \\
Leukocytes & 400 & $8.3 \pm 0.37^{*}$ \\
& Control & $5.612 \pm 2.47$ \\
& 100 & $14.187 \pm 3.87^{*}$ \\
Hemoglobin & 200 & $9.037 \pm 2.40^{*}$ \\
& 400 & $11.287 \pm 4.08^{*}$ \\
& Control & $9.78 \pm 0.95$ \\
& 100 & $13.68 \pm 0.48^{*}$ \\
& 200 & $14.97 \pm 0.47^{*}$ \\
& 400 & $14.67 \pm 0.91^{*}$ \\
\hline
\end{tabular}

Note :

$*=\mathrm{p}<0.05$ (Has significantly differences to the control)

\subsubsection{Erythrocytes}

Data on the number of erythrocytes that analyzed using parametric statistics, it showed differences between the treatment groups. However, if viewed from a normal mouse $\left(5.00\right.$ to $\left.10.00 \mathrm{million} / \mathrm{mm}^{3}\right)$; the increasing in the value of the erythrocytes in the treatment group was still within the normal range, it concluded that the ethanol extract of green algae did not affect the number of erythrocytes. 


\subsubsection{Leukocyte}

Normality test of leukocyte count has generated significant value $(p>0.05)$, which means the data was homogeneous. Further analysis of parametric statistical one way ANOVA showed there was significant differences when compared with the control group $(p<0.05)$. It means that the treatment of ethanol extract of green algae for 28 days did not affect the number of leukocytes. The situation which characterized by an increased number of leukocytes above normal number is called leukositas. If this increase is very high (up to 300,000 cells $/ \mathrm{mm} 3$ ) is called leukemia while moderate decrease in leukocytes is called leukopenia [14].

\subsubsection{Hemoglobin Level}

The results of the analysis of the number of leukocytes after statistical tested by one way ANOVA showed that dose group of $100 \mathrm{mg} / \mathrm{kg}$, a dose of $200 \mathrm{mg} / \mathrm{kg}$ and $400 \mathrm{mg} / \mathrm{kg}$ had a significant difference compared with the control group $(\mathrm{p}<0.05)$, which was an increased in value blood hemoglobin in rat. However, the increased in hemoglobin levels were still within the normal range (11.0 to $19.0 \mathrm{~g} / \mathrm{dL})$. Therefore it can be concluded that the ethanol extract of green algae did not give effect to changes in blood hemoglobin levels.

\subsection{Blood Hemostasis Parameter}

Hemostasis is the mechanism of the body to prevent and stop the bleeding. Overview of hemostasis were tested in this study include bleeding time/BT, prothrombin time/PT, activated partial thromboplastine time/aPTT and count the number of platelets. The hematological parameters of hemostatis were collected in Table 2. Bleeding Time / BT or bleeding time is an examination to determine the function of vasoconstriction of the blood vessels in the event of injury. Inspection plasma prothrombin time (Prothrombin Time/PT) is used to test coagulation factors through the extrinsic pathway and along paths that coagulation factors VII, X, $\mathrm{V}$, prothrombin and fibrinogen. APTT examination serves to test the intrinsic pathway of coagulation factors and pathways along which the coagulation factors V, VIII, IX, XII, prekalikren, kininogen, prothrombin, and fibrinogen. While the number of platelet count has a function to evaluate the function of platelets in order to clog of small holes in blood vessels.

Table 2. Results Calculated Hematological Parameters of Hemostasis Rats after Ethanol Extract of Green Algae were given for 28 Days

\begin{tabular}{|c|c|c|c|c|}
\hline \multirow[b]{2}{*}{ Group } & \multicolumn{4}{|c|}{ Hemostasis Parameter } \\
\hline & $\begin{array}{l}\text { BT (second) } \\
(\mathrm{n}=8)\end{array}$ & $\begin{array}{l}\text { PT (second) } \\
(\mathrm{n}=8)\end{array}$ & $\begin{array}{l}\text { aPTT (second) } \\
\quad(n=8)\end{array}$ & $\begin{array}{c}\text { Number of Thrombosis } \\
\left(10^{\wedge} 9 / \mathrm{L}\right)(\mathrm{n}=8)\end{array}$ \\
\hline Control & $643.875 \pm 131.280$ & $30.125 \pm 2.416$ & $48.000 \pm 4.071$ & $223.625 \pm 92.325$ \\
\hline $100 \mathrm{mg} / \mathrm{kgBB}$ & $756.875 \pm 145.840$ & $23.125 \pm 1.808^{*} \downarrow$ & $39.875 \pm 2.031 * \downarrow$ & $795.750 \pm 242.959 * \uparrow$ \\
\hline $200 \mathrm{mg} / \mathrm{kgBB}$ & $587.875 \pm 214.109$ & $21.750 \pm 8.137 * \downarrow$ & $64.250 \pm 5.445^{* \uparrow}$ & $818.750 \pm 206.259^{*} \uparrow$ \\
\hline $400 \mathrm{mg} / \mathrm{kgBB}$ & $686.500 \pm 232.408$ & $13.250 \pm 1.282 * \downarrow$ & $40.625 \pm 1.685 * \downarrow$ & $821.125 \pm 320.983 * \uparrow$ \\
\hline
\end{tabular}

The results of the ANOVA statistical test showed no significant difference for BT $(\mathrm{p}=0.337>0.05)$. This is due to differences in the vascular integrity of each rat were not the same and the human skills in conducting examinations even though the distance cuts already equated in $5 \mathrm{~mm}$ from the tip of the tail. The parameters of PT, aPTT and platelet count were significant differences between the treatment group and the control group $(\mathrm{p}=<0.05)$. PT test results shorten on the treatment group compared to the control group. Shortening of PT was associated with melatonin dose given, the greater the dose given, the shortening of the PT is also getting bigger. It was because the increased of fibrinogen, von Willebrand factor increased, PAI-1 increased, and fibrinolysis decreased.

The test employed aPTT test results has Shortened at a dose of $100 \mathrm{mg} / \mathrm{kg}$ and $400 \mathrm{mg} / \mathrm{kg}$, it is due to increased fibrinogen, von Willebrand factor increased, fibrinolysis decreased. However, on examination of aPTT at dose of $200 \mathrm{mg} / \mathrm{kg}$, the aPTT become lengthwise, it caused by endothelial dysfunction which would degrade the coagulation factors V, VIII, IX, X, XI, XII, prothrombin, fibrinogen, prekalikren, kininogen, which increase fibrinolysis activity and decreased the levels of fibrinogen which are usually caused by the presence of inhibitors and deficiency coagulation factor VIII, IX, XI, XII, prothrombin, fibrinogen, prekalikrean, and kininogen. The examination results of count the number of platelets in the hematology 
analyzer tool showed the significant differences, the number of platelets have significantly increased due to the effect of melatonin which is also consistent with studies that have been conducted [15].

\subsection{Parameters Blood Immunity}

Immunity refers to the body's ability to resist or eliminates the abnormal cells or foreign objects that have potential to damage. Leukocytes and it derivatives (lymphocytes, monocytes, eusinofil, and neutrophil segments) can resists an invasion by pathogens (disease-causing microorganisms, such as bacteria and viruses) through the process of phagocytosis, identify and destroys cancer cells that appears in the body and cleaning the body with debris fagocyt which comes from the dead or injured cells [16]. The parameters of immunity were calculated in Table 3.

Table 3. The result of the Parameters Calculation on Immunity of Rat after Ethanol Extract of Green Algae was given for 28 Days

\begin{tabular}{lcc}
\hline Group & Dosage $(\mathrm{mg} / \mathrm{kg} \mathrm{bw})$ & $\mathrm{X} \pm \mathrm{SD}(\mathrm{g} / \mathrm{dL})$ \\
\hline Neutrophil segment & Control & $82.875 \pm 3.441$ \\
& 100 & $78.125 \pm 5.866$ \\
Monocytes & 200 & $80.500 \pm 7.309$ \\
& 400 & $76.125 \pm 9.234$ \\
& Control & $2.000 \pm 0.756$ \\
Eosinophils & 100 & $1.000 \pm 1.069$ \\
& 200 & $0.750 \pm 1.035$ \\
& 400 & $1.250 \pm 1.581$ \\
Lymphocytes & Control & $1.750 \pm 2.187$ \\
& 100 & $1.750 \pm 1.069$ \\
& 200 & $1.250 \pm 1.035$ \\
& 400 & $1.500 \pm 1.581$ \\
& Control & $1.750 \pm 2.187$ \\
& 100 & $1.750 \pm 1.069$ \\
& 200 & $1.250 \pm 1.035$ \\
\hline
\end{tabular}

$*=p<0.05$ (has significantly different to the control)

\subsubsection{Number of Neutrophils}

The number of average neutrophils segment in all dose groups of ethanol extract of green algae was higher than the control and there are no significantly differences that mean the ethanol extract of green algae did not affect on the number of neutrophil segments. The normal value of neutrophils segment in rat is 18.0 to $35 \%$ [16].

\subsubsection{Number of Lymphocytes}

The average number of lymphocytes in the group dose of $200 \mathrm{mg} / \mathrm{kg}$ of ethanol extract of green algae was higher compare the control, it causes the ethanol extract of green algae at a dose of $200 \mathrm{mg} / \mathrm{kg} \mathrm{has}$ effected on lymphocyte count. But overall there are no significant differences, it means the ethanol extract of green algae does not affect to the number of lymphocytes. According Schalm's Veterinary Hematology [17] the normal value of lymphocytes in rat is $84.8 \pm 8.3 \%$, while the number of lymphocytes of normal rat is $62-75 \%[16]$.

\subsubsection{Number of Monocytes}

The average number of monocytes in a dose group of $400 \mathrm{mg} / \mathrm{kg}$ of ethanol extract of green algae was higher compare the control; it caused the ethanol extract control of green algae at a dose of $400 \mathrm{mg} / \mathrm{kg}$ affected on lymphocyte number. In overall there were no significant differences, the ethanol extract of green algae did not affect the number of monocytes. The normal value of monocytes is $0-6 \%$.

\subsubsection{Number of Eosinophils}

The average number of eosinophils in all dose groups of ethanol extract of green algae was lower compares the control and there were no significant differences in the ethanol extract of green algae did not affect the number of eosinophils. The normal value of eosinophils is 1-4\% [18]. 


\section{CONCLUSION}

Based on hematological examination and statistical analysis of ethanol extract of green algae for 28 days has increased the general hematological parameters (erythrocytes, leukocytes, and hemoglobin concentration), and may affect the function of hemostasis by activating the coagulation of extrinsic and the intrinsic pathway, based on PT parameters and aPTT. Giving EEGH has increased the number of platelets but has not affected to BT, and has a role to stimulate immune activity by increasing the number of leukocytes, especially neutrophils segments in all treatment groups, the lymphocytes in the group of $200 \mathrm{mg} / \mathrm{kg}$, monocytes in a dose group of $400 \mathrm{mg} / \mathrm{kg}$. The increase in the number of leukocytes is acting as an effort to maintain the body's immune system when a foreign substance possessed. Therefore it can be concluded that the ethanol extract of green algae has no harmful effect.

\section{ACKNOWLEDGEMENTS}

This research paper is made possible though the fund support from Ministry of Higher Education Republic of Indonesia.

\section{REFERENCES}

[1] Kolar J. and Machanckova I., "Occurrence and possible function of melantonin in plants," Endocytobiosis and Cell Res, vol/issue: 14(1), pp. 75-84, 2001.

[2] T. Kiefer, et al., "Melatonin inhibits estrogen reseptor transactivation and cAMP levels in breast cancer cells," Breast Cancer Research and Treatment, vol/issue: 71(1), pp. 37-45, 2002.

[3] V. Lenoir, et al., "Preventif and curative effect of melatonin on mammary carcinogenesis induced by dimethylbenz (a) anthracene in the female Sprague-Dawley rat," Breast Cancer Research, vol/issue: 7(10), pp. 470-476, 2005.

[4] E. Ozan, et al., "Effects of melatonin and vitamin C on cigarette smoke-induced damage in the kidney," Toxicol Ind Health, vol/issue: 23(8), pp. 479-564, 2007.

[5] A. Baykan, et al., "The Protective Effects of Melatonin on nicotine-induced myocardial injury in newborn rats whose mothers received nicotine," Anadolu Kardiyol Derg, vol/issue: 8(4), pp. 243-251, 2008.

[6] Koh P. O., "Melatonin prevents ischemic brain injury through activation of the Mtor/p70S6 kinase signaling pathway," Neurosci Lett, vol/issue: 14(5), pp. 134-139, 2008.

[7] Lin A. M., et al., "Melatonin inhibits arsenite-induced peripheral neurotoxicity," J Pineal Res, vol/issue: 18(6), pp. 34-51, 2008.

[8] Varvares M. A., "Management of Oral Cavity Carcinoma," Mo Med, vol/issue: 105(3), pp. 244-253, 2008.

[9] Xia C. M., et al., "Effects of melatonin on blood pressure in stress-induced hypertension in rats," Clin Exp Pharmacol Physiol, vol/issue: 32(8), pp. 162-169, 2008.

[10] Wirtz P. H., et al., "Oral Melatonin Reduces Blood Coagulation Activity: A Placebo-Controlled Study in Healthy Young Men," Departement of Clinical Psychology and Psychotherapy University of Zurich, 2008.

[11] I. I. Pashalieva, et al., "Screening Study of Melatonin Effects on Basic Integral Parameters of Blood Coagulation (PT, APTT, TT, ECLT)," Acta Physiologica, vol/issue: 03(686), 2011.

[12] H. Notopuro, "Examination PT dan APTT to support the Diagnosis Clinic," Conference of Faal Hemostasis PATELKI, 2002.

[13] Rosidah, et al., "Toxicology evaluation of standardized methanol extract of Gynura procumbens," Journal of Ethnopharmacology, vol. 123, pp. 244-249, 2009.

[14] S. A. Price and L. M. Wilson, "Patofisiologi, the concept of clinical disease processes," EGC, vol/issue: 1(6), 2006.

[15] Sherwood L., "Physiology from cell to system," Jakarta, EGC, pp. $601-606,2001$.

[16] B. Hariono, "Guidelines for college pathology clinic", the pathology lab clinic, the Faculty of Veterinary Medicine, UGM, 2005.

[17] A. V. Hoffbrand, et al., "Capita selekta hematology, 4th Ed," EGC, 2005.

[18] Xia C. M., et al., "Effects of melatonin on blood pressure in stress-induced hypertension in rats," Clin Exp Pharmacol Physiol, vol/issue: 32(8), pp. 162-169, 2008. 